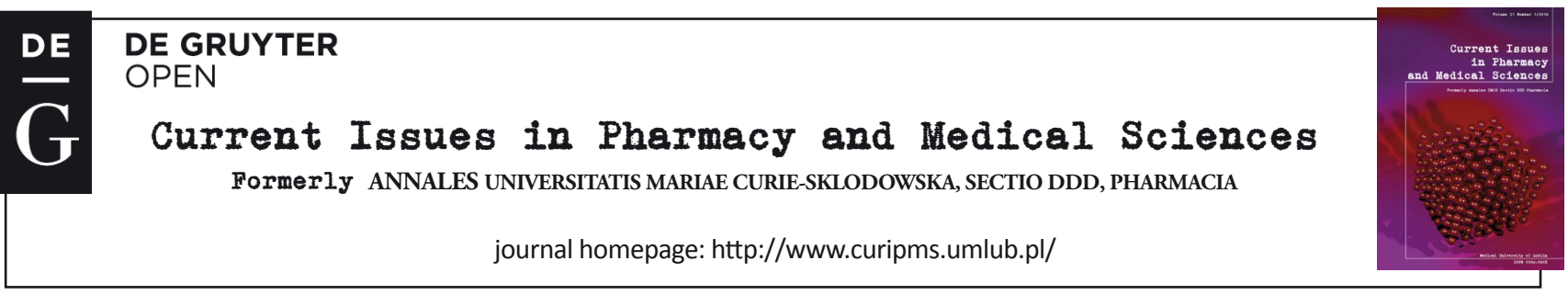

\title{
Chemical composition, toxicity, and acaricidal activity of Eucalyptus globulus essential oil from Algeria
}

\author{
Ghania Atmani-Merabet ${ }^{1,2,3 *}$, Abdelmalik Belkhiri ${ }^{1,2}$, Mohamed Abdeslam Dems ${ }^{4}$, \\ Abdeldjallil Lalaouna ${ }^{1}$, Zakaria KhalfaOui ${ }^{5}$, Bouzid Mosbah ${ }^{6}$
}

\author{
${ }^{1}$ Departments of Dental Surgery and Pharmacy, Laboratory of Pharmacognosy, Salah Boubnider University Constantine 3, Algeria \\ ${ }^{2}$ Laboratory of Pharmacology and Toxicology, Mentouri University Constantine 1, Algeria \\ ${ }^{3}$ Departments of Chemistry, Faculty of Sciences, Mentouri University Constantine 1, Algeria \\ ${ }^{4}$ Biotechnology Research Centre (Crbt Constantine), Constantine, Algeria \\ ${ }^{5}$ Technical Institute of Breeding (ITE Hamma Bouziane), Constantine, Algeria \\ ${ }^{6}$ Forest Conservation in Constantine, Algeria
}

\section{ARTICLE INFO \\ Received 18 December 2017 \\ Accepted 15 February 2018}

\section{Keywords:}

Eucalyptus globulus,

leaf essential oil,

thymol,

toxicity,

Varroa destructor.

\begin{abstract}
The study was aimed at determining the chemical composition, toxicity effect and field varroacidal efficacy of the essential oil distilled from the leaf of Eucalyptus globulus (Eg) grown in Algeria. Brine shrimp lethality (BSL) assay and bee hives infected by Varroa destructor were used to assess the toxicity and acaricidal effect, respectively. Steam distillation of leaves yielded $0.93 \%(\mathrm{v} / \mathrm{w})$ of essential oil (EO). GC/MS Analysis revealed 39 compounds, essentially oxygenated monoterpenes (86.01\%). The main constituents of the oil were 1,8-cineole (78.45\%), o-cymene (2.18\%), isopinocarveole (1.74\%), $\alpha$-pinene (1.69\%), pinocarvone (1.34\%) and veridiflorol (1.31\%). The BSL assay revealed a highly toxic value of LC50 $(67.55 \mu \mathrm{g} / \mathrm{mL})$. Furthermore, field efficacy testing on bee hives infected with Varroa destructor has confirmed the effectiveness of Eucalyptus globulus essential oil (EgEO) or thymol as varroacidal agents. Moreover, a EgEO + thymol association was more effective than EgEO or thymol alone. Finally, the use of EgEO + thymol may constitute a viable alternative to the thymol-based commercial treatment.
\end{abstract}

\section{INTRODUCTION}

Varroa destructor is an ectoparasite that contributes to the collapse of bee colonies, resulting in economic losses and ecological problems related to the role of bees as the most important pollinators on Earth [1]. Varroatosis has been treated by methods that include special apiculture practices (mesh floors, smoke, selection of resistant bees etc.) biological and chemical approaches [2-4]. Synthetic pesticides have been widely used throughout the world, however, they have often proved to be harmful to the environment and pose potential risks of contamination of honey and other hive products with chemical residues [5]. There is also clear evidence for the evolution of resistance in Varroa mite populations to conventional pesticides [6]. Given this situation, where the number of infected bee colonies is increasing steadily, there is an urgent need for an effective and environmentally-friendly means of control available to beekeepers. This problem has led to the appearance of several programs

\footnotetext{
* Corresponding author

e-mail: mgachimie2014@hotmail.com
}

of prospecting natural products with anti-varroa potential [7-10]. Commercially available botanical products include formulations based on natural molecules such as camphor, thymol, and eucalyptol. Thymol-based formulations (e.g. Apiguard $\AA$, Thymovar $\AA$ ) are particularly effective, with a percentage that exceeds $90 \%$ [11]. Although thymol treatment has been shown to be effective in neutralizing mites, volatility problems have arisen [12], and treatment based solely on thymol may generate the potential resistance of $V$. destructor [13]. A special practice of local beekeeping in the forest regions of Skikda (city by the sea, $471 \mathrm{~km}$ from Algiers) is to combine conventional treatments with aromatic plants for better efficiency and lasting effect, thus, Eucalyptus leaves are used as fumigation in nearby hives. The efficacy of this traditional practice is plausible given the many scientific studies supporting the insecticidal properties of Eucalyptus essential oils [10-14].

A large number of Eucalyptus species have been introduced in Algeria, notably by the French settlers from 1864 to 1876 [15]. Eucalyptus globulus of the Myrtaceae family, 
also known as Tasmanian blue gum or blue gum, is one of the species originated from Australia which has well acclimated in Algeria, especially in the northern part where it found a favorable climate for its development. Eucalyptus leaves are largely used in the Algerian folk medicine for a range of therapy conditions. For instance, vapor from a hot water extract of the dried leaves is inhaled to retrieve symptoms associated with respiratory infections, such as cold, flue and sinus congestion [16].

The chemical composition of EgEO has revealed more than twenty compounds with 1,8-cineole, $\alpha$-pinene and $\delta$-limonene as major constituents $[17,18]$. EgEO is also widely used in modern cosmetics, food and pharmaceutical industries [19]. EgEO was shown to possess anti-inflammatory, analgesic, antiviral, antimicrobial, antioxidant and insecticidal activities [20,21]. Moreover, its has exhibited a varroacidal activity against $V$. destructor $[1,2,9,10]$. Essential oils components offer an attractive alternative to synthetic acaricides for the control of $V$. destructor. They are generally inexpensive and most pose few health risks. It is on this basis that we have studied the chemical composition, the acaricidal and toxic effects of the essential oil extracted from the leaves of Eucalyptus globulus.

This study is initiated on the basis that thymol is a product whose efficacy in the control of mites is established and that this effect could be potentiated by combining it with local Eucalyptus essential oils. The ultimate goal is to develop new products which are more efficient, but, above all, will overcome the problem of increasing pest resistance to treatments.

\section{MATERIALS AND METHODS}

\section{Plant material and distillation}

Leaves were collected in April 2014 at the herbarium of "Draa Naga" Djbel El Ouahch, located at $15 \mathrm{~km}$ east of Constantine, Algeria. The study area (Draa Naga herbarium) is situated between the longitude X1: $6^{\circ} 42^{\prime} 5^{\prime \prime}, \mathrm{X} 2$ : 6 ${ }^{\circ} 42^{\prime} 30^{\prime}$ ” and the latitude Y1: $36^{\circ} 20^{\prime} 45^{\prime \prime}, \mathrm{Y} 2: 36^{\circ} 22^{\prime} 15^{\prime \prime}$. Eucalyptus globulus was identified by a taxonomist (Dr Bouzid Mosbah) and the voucher specimen (Eg006501) was deposited for future reference at the herbarium of the Constantine Forestry Conservation. Essential oil was extracted from fresh leaves (1400 g) by steam distillation using a Clevenger apparatus for 4 hours. Distilled oil was immediately dried over anhydrous sodium sulfate and stored in screw-capped dark glass vials at $4^{\circ} \mathrm{C}$ until further testing.

\section{GC/MS analysis}

Essential oil extracted from the leaves of Eucalyptus globulus was analysed by a gas chromatograph coupled with mass spectrometer "GC/MS" (Agilent System HP-5MS.) as described below: Capillary chromatographic column of $30 \mathrm{~m}$ (length), $0.25 \mathrm{~mm}$ (diameter), and $25 \mu \mathrm{m}$ (film thickness)], with apolar stationary phase of 5\% phenyl and 95\% dimethyl polysiloxane. Column compartment temperature was programmed from 50 to $200^{\circ} \mathrm{C}$ for $10^{\circ} \mathrm{C} / \mathrm{min}$; GC/MS interface was maintained at $230^{\circ} \mathrm{C}$ and the ionization source at $150^{\circ} \mathrm{C}$; Helium was used as gas vector with a flow of $0.5 \mathrm{ml} / \mathrm{min}$; Injection volume was $0.5 \mu \mathrm{l}$; MS ionisation energy was $70 \mathrm{ev}$ with scan band of 45-400 u. The essential components were tentatively identified by comparison with mass spectra data (MS) obtained from NIST-Wiley-MS library and confirmed by comparison with Kovats index on HP-5MS column.

\section{BIOACTIVITY}

\section{Brine Shrimp lethality assay}

The brine shrimp lethality (BSL) assay was used to predict the toxicity of the essential oil, as previously described [22]. Different concentrations (1000, 100, 10, $1 \mathrm{ppm}$ ) of EgEO were prepared using dimethyl sulfoxide (DMSO 1\%). After $48 \mathrm{~h}$, a drop of DMSO and $4 \mathrm{ml}$ of sea water were added to each of the sample bottles containing the oil sample; Ten brine shrimp larvae of Artemia salina were carefully counted into each of the sample bottles and the volume of the sea water was made up to $5 \mathrm{ml}$. Tests for each concentration was done four times, and a control experiment containing $5 \mathrm{ml}$ of sea water, a drop of DMSO and ten brine shrimp larvae was set along side. The experiment was maintained at room temperature for $24 \mathrm{hrs}$, the number of surviving larvae were counted and recorded, and the data obtained were subjected to Finney's probit analysis to determine the "LC50" of the oil.

\section{ACARICIDAL ACTIVITY}

\section{Experimental apiary}

This Experiment was conducted in an apiary located in nearby Azzaba $\left(36^{\circ} 45^{\prime} 41.1^{\prime \prime} \mathrm{N}, 7^{\circ} 03^{\prime} 50.3\right.$ 'E). Langstroth type hives of bees (Apis mellifera) whose colonies were infected with $V$. destructor were randomly assigned into four batches: batch 1 to 3 was treated with ( $1 \mathrm{~mL} /$ hive/week) of each of EgEO, thymol, and EgEO + thymol (v/v) [2]. Batch 4 was used as a control (untreated hives).

\section{Collection, counting and analysis}

The method followed is the biological method deemed "raised diapers" or "covers background" [2,3]. This method is designed to track and count the fallen mites. Vaseline greased diapers are first placed in the hive, then removed and carefully examined with a hand lens to detect the dead Varroa. This method lasts 21 days, during which the counting is done every two days. After each count, the diapers are thoroughly cleaned and then replaced. The essential oil is deposited on a cardboard tab of $1 \mathrm{~mm}$ thickness to a width of $4 \mathrm{~cm}$ and a length of $20 \mathrm{~cm}$, the deposited volume is $1 \mathrm{ml}$ [2]. The tab is inserted through the main entrance of the hive; the treatment is repeated at the $7^{\text {th }}$ day and then continues to the $14^{\text {th }}$ day. The results are expressed in means of mortality \pm standard deviation. The temperature during the experiment varied between $20^{\circ} \mathrm{C}$ and $22^{\circ} \mathrm{C}$.

\section{RESULTS AND DISCUSSION}

\section{Yield of essential oil}

The essential oil extracted from the Eg leaves was yellow colored and had a camphor-like smell and pleasant odor, as previously described $[17,23]$. The extraction yield of essential oil was $0.96 \%$, a value within the range of those 
previously reported [24-27]. Of note, disparity of yields in the same species can be linked to genetic and environmental factors, time of collection and extraction method [28].

\section{GC/MS analysis of essentials oils}

The results of the GC/MS analysis revealed 39 compounds (Table 1), essentially oxygenated monoterpenes $(86.01 \%)$, monoterpenes $(5.74 \%)$, monoterpenes alcohols $(4.05 \%)$ and sesquiterpenes alcohols $(2.74 \%)$ (Table 2$)$. The main constituents of the oil were 1,8-cineole (78.45\%), o-cymene $(2.18 \%)$, isopinocarveole $(1.74 \%), \alpha$-pinene $(1.69 \%)$, pinocarvone (1.34\%) and veridiflorol (1.31\%).

Table 1. Chemical composition of leaf essential oil of E.globulus

\begin{tabular}{|l|c|c|}
\hline \multicolumn{1}{|c|}{ Compounds } & KI & \% composition \\
\hline 1,8-cineole & 1030 & 78.45 \\
\hline o-cymene & 1026 & 2.18 \\
\hline Isopinocarveole & 1226 & 1.74 \\
\hline alpha-pinene & 939 & 1.69 \\
\hline alpha-terpineol & 1189 & 1.36 \\
\hline Pinocarvone & 1165 & 1.34 \\
\hline Veridiflorol & 1593 & 1.31 \\
\hline (+) spathulenol & 1578 & 1.05 \\
\hline trans-p-mentha-1 (7), 8-dien-2-ol & 1185 & 0.79 \\
\hline methyl benzene & 773 & 0.77 \\
\hline Camphene & 954 & 0.7 \\
\hline cis-p-mentha-1 (7),8-dien-2-ol & 1235 & 0.51 \\
\hline 4-terpineol & 1177 & 0.5 \\
\hline 1-phellandrene & 1003 & 0.35 \\
\hline thymol & 1290 & 0.28 \\
\hline Ledol & 1569 & 0.28 \\
\hline trans-carveol & 1217 & 0.22 \\
\hline butylester & 2388 & 0.17 \\
\hline D-carvone & 1243 & 0.16 \\
\hline alpha-selinene & 1498 & 0.14 \\
\hline beta-myrcene & 991 & 0.13 \\
\hline Myrtenol & 1327 & 0.13 \\
\hline 2-beta-pinene & 979 & 0.12 \\
\hline Valencene & 1496 & 0.11 \\
\hline gamma-terpinene & 1060 & 0.1 \\
\hline Isospathulenol & 1644 & 0.1 \\
\hline KI: compornds w & \\
\hline
\end{tabular}

KI: compounds were tentatively identified by comparison with mass spectra data (MS) obtained from NIST-Wiley library and confirmed by comparison with Kovats index on HP-5MS column. (\%) composition: percentage of concentrations based on peak area integration

Table 2. The percentage of particular groups of E. globulus essential oil components

\begin{tabular}{|l|c|}
\hline \multicolumn{1}{|c|}{ Groups } & Percentage (\%) \\
\hline Monoterpenes & 5.47 \\
\hline Oxygenated monoterpenes & 78.45 \\
\hline Monoterpenes alcohols & 4.05 \\
\hline Monoterpenes ketones & 3.41 \\
\hline Monoterpenes aldehydes & 0.1 \\
\hline Sesquiterpenes & 0.65 \\
\hline Sesquiterpenes alcohols & 2.74 \\
\hline Aromatic hydrocarbons & 0.87 \\
\hline Aldehydes & 0.16 \\
\hline Esters & 0.27 \\
\hline
\end{tabular}

Previous investigations of EgEO have revealed various chromatographic profiles with different percentages of 1,8cineole [29]. For example, EgEO samples from Brazil and Australia showed a high amount of 1,8-cineole, with an average of 85 and $90 \%$, respectively [30,31]. In contrast, an analysis of a Eucalyptus oil sample from Argentina displayed a moderate percentage of $60 \%$ [32], while those of Morocco and Kenya gave a low percentage - with an average of 22.4 and $17.22 \%$, respectively [26,33]. Studies from Algerian EgEO collected from different sites revealed a variability in the composition from 47.05 to $53.3 \%$ [23,34]. These variations in Algeria EgEO and those of elsewhere denote the existence of several chemotypes, as previously reported [29].

\section{BIOACTIVITY}

\section{Toxicity and acaricidal activity}

The result of the brine shrimp lethality assay of EgEO is shown in (Table 3). The (BSL) test revealed a value of "LC50" of $67.55 \mu \mathrm{g} / \mathrm{mL}$. According to the toxicity scale established previously by Clarkson et al., the value of "LC50" obtained for EgEO is considered as highly toxic [35]. It is worth noting that the toxicity of our EO is lower than that obtained from a Nigerian sample which showed on the same assay an "LC50" value of $9.59 \mu \mathrm{g} / \mathrm{mL}$ [24]. The Nigerian EO has a different composition, with terpinen-4-ol at $23.46 \%$ and $\delta$-terpinene at $17.01 \%$ as predominant components, while 1,8 -cineole was present with only a $2.52 \%$. This low value of 1,8-cineole suggest that other constituents of the Nigerian EgEO might contribute to its toxicity.

Table 3. Brine shrimp lethality assay of leaf extracts of E. globulus essential oil

\begin{tabular}{|c|c|c|c|c|}
\hline Plant extract & $\begin{array}{c}\text { Dose } \\
(\mu \mathrm{g} / \mathrm{mL})\end{array}$ & $\begin{array}{c}\text { Nbre of tested } \\
\text { shrimps }\end{array}$ & $\begin{array}{c}\text { Nbre of } \\
\text { survivors }\end{array}$ & $\begin{array}{c}\text { "LC50" } \\
(\mu \mathrm{g} / \mathrm{mL})\end{array}$ \\
\hline \multirow{5}{*}{ E. globulus } & 1 & 40 & 13 & \\
& 10 & 40 & 20 & 67.55 \\
& 100 & 40 & 25 & \\
\hline
\end{tabular}

The results of the field acaricidal testing of EgEO are shown in (Figure 1). All treated infected bee hives have showed significant fall of Varroa destructor compared to the control. The EgEO + thymol-treated batch showed as being the most efficient in removing the ectoparasite compared to the thymol $(\mathrm{p}=0.05)$ and $\operatorname{EgEO}(\mathrm{p}=0.006)$ batches.

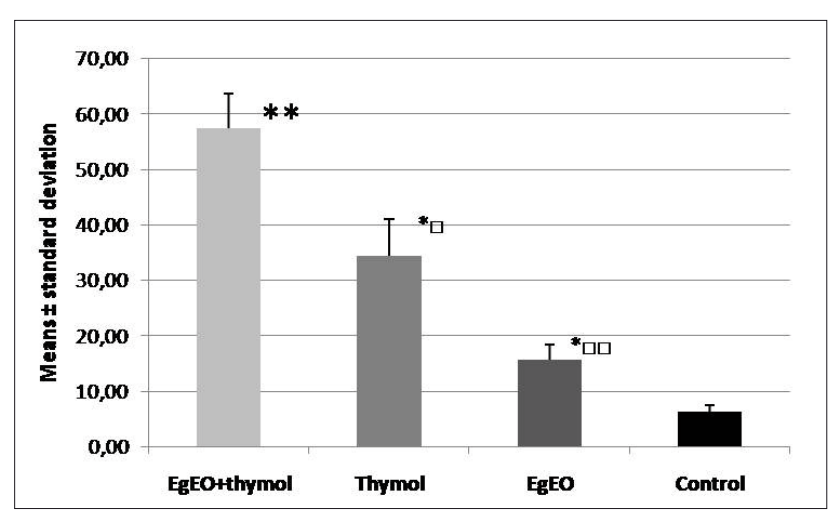

Value of fallen Varroa expressed as means $\pm S D(n=3)$; $(* * \mathrm{p}<0.01, * \mathrm{p}<0.05)$ value vs control;

( $\square \mathrm{p}<0.01$, $\square \mathrm{p}<0.05$ ) value vs (EgEO \pm thymol) treatment

Figure 1. Number of dead Varroa expressed as means \pm SD 
However, no significant difference was observed between the thymol and the EgEO treated batches. Despite the situation that EgEO alone has a lower value of fallen Varroa $(15.60 \pm 2.70)$ than that of thymol $(34.37 \pm 6.56)$, the difference is not significant $(\mathrm{p}=0.07)$.

Several studies have been conducted world-wide, to understand the effectiveness of essential oils against Varroa destructor [29]. Aromatic species such as Ferula assa-foetida. Allium sativum. Sizygium aromaticum, Piper aduncum, Thymus spp., Eucalyptus spp. has been tested successfully against the ectoparasite [29]. The acaricidal activity of EOs from $E$. camaldulensis on $V$. destructor mite was also investigated, and a LD50 of $1.74 \mu \mathrm{L} / \mathrm{L}$ was found [8]. A previous study using Eucalyptus globulus EO at a level of $10 \mu \mathrm{L}$, has showed an acaricidal effect of $45.75 \%$ of dead Varroa [10]. Our result revealed a slightly lower toxic effect toward the ectoparasite than the last study. This difference may be justified by the more important number of repeated treatments used by this study [10]. Finally, all these studies have outlined the usefulness of an EgEO treatment against Varroa destructor.

Despite the fact that the thymol treated group has shown a higher percentage of fallen Varroa than that of EgEO, no statistically difference between the two groups was observed. One of the reasons might be linked to the high variability detected in the apiary. To overcome this issue, the number of hives and apiaries that form such a study must be raised to obtain a better understanding of the effects of the applied treatments. It should be underlined that the most important fall of the ectoparasite was recorded with the association of EgEO + thymol. This result is significant and raises other crucial issues. Among the raised questions is whether the observed effect of EgEO is attributable or not to 1,8 -cineole?, if this is the case, it will be interesting to investigate the association of thymol $+1,8$-cineole as a potential acaricide.

\section{CONCLUSION}

The chemical analysis of EgEO revealed a composition dominated by oxygenated monoterpènes in the main, represented by 1,8 -cineole. Our study has confirmed that an $\mathrm{EgEO}+$ thymol association was more effective in reducing the ectoparasite populations than was EgEO or thymol alone. This result is interesting in that the use of EgEO+thymol may constitute a viable alternative to thymol-based commercial treatment. Finally, the use of a natural pesticide is of immense significance in view of the environmental and toxicological implications of the indiscriminate use of synthetic pesticides and in view of the need to overcome the problem of the increasing pesticide resistance of $V$. destructor.

\section{ACKNOWLEDGEMENTS}

We are very grateful to Mr. Mokadem Hamadi, a private beekeeper, who allowed us to use a part of his apiary for experimental purposes.

\section{CONFLICTS OF INTEREST}

The authors declare no conflict of interest.

\section{REFERENCES}

1. Kluser S, Neumann P, Chauzat MP, Pettis JS. Global honey bee colony disorder and other threats to insect pollinators. UNEP Emerging Issues 1, Kenya; 2002:1-12.

2. Labeste L. Protocole de traitement aux huiles essentielles - activité acaricide sur le Varroa. Apisevices-Galerie Virtuelles Apicoles, France; 2013.

3. Ghomari FN, Kaouache B, Arous A, Cherchali S. Effet de traitement par fumigation du thym (Thymus vulgaris) sur le Varroa destructor agent de la varroase des abeilles. Revue Nature et Technologie: B-Sci Agro et Bio. 2014;10:34-8.

4. Adjlane N, El Ounass J, Haddad N. Situation de l'apiculture en Algérie: facteurs menaçants la survie de colonies d'abeilles locales Apis mellifera Intermissa. J. Arthropod-Born.Dis. 2016;10(4):501-8.

5. Bogdanov S, Charriere JD, Imdorf A, Kilchenmann V. Determination of residues in honey after treatment with formic and oxalic acid under field conditions. Apido. 2002;33:399-9.

6. Umpiérrez ML, Santos E, González A, Rossini C. Plant essential oils as potential control agents of varroatosis. Phytochem Rev. 2011;10(2):227-4.

7. Abdelwahab TE, Ebadah MA, Zidan EW, Evaluation of some volatile plant oils and maurik against Varroa destructor in honey bee colonies. J of Appl Sci Res. 2006;2(8):514-21.

8. Ghasemi V, Moharramipour S, Tahmasbi G. Biological activity of some plant EOs against Varroa destructor (Acari: Varroidae), an ectoparasitic mite of Apis mellifera (Hymenoptera: Apidae). Exp Appl Acarol. 2011;55:147-54.

9. Mahmoud R, Asad S, Raja S, UL Moshina A, Wagchoure ES, Sarwar $\mathrm{G}$, et al. Control of Varroa destructor (Acari: Varroidae) in Apis mellifera. (Hymenoptera: Apidae) by using Plant Oils and Extract. Pakistan. J. Zool 2014;46(3):609-15.

10. Habbi-Cherif Aisssa. Etude de la dynamique du parasite Varroa destructor de l'abeille domestique (Apis mellifera) et évaluation de l'efficacité de quelques huiles essentielles dans la lutte contre ce parasite. Mémoire de Magister, Université MouloudMameri,TiziOuzou, Algria; 2014.

11. Coffey MF, Breen J.Efficacy of ApilifeVar ${ }^{\oplus}$ and Thymovar ${ }^{\oplus}$ against $^{-}$ Varroa destructor as an autumn treatment in a cool climate. J of Apicu Res. 2013;52(5):210-18.

12. Shahrouzi R. La varroatose en Iran. Abeilles \& c $c^{\text {ie }}, 2004 ; 103: 24-25$.

13. Rosenkranz P, Aumeier P, Ziegelmann B. Biology and control of Varroa destructor. J of Invert Patho. 2010;103:96-119.

14. Shengping PJYQQ, Lihua LCW. Study of the niche transition of lesser Asian mite (Tropilaelapsclareae) in honey bee colony just after infection desynchronisation of larger varroa mite (Varroa destructor). Apicul of China. 2011.

15. Boulekbache-Makhlouf L, Meudec E, Chibane M, Mazauric JP, Cheynier V, Slimani S, et al. Analysis of phenolic compounds in fruit of Eucalyptus globulus cultivated in Algeria by high-performance liquid chromatography diode array detection mass spectrometry. J. Agric. FoodChem. 2010;58:12615-24.

16. Cermelli, A. Fabio, G. Fabio, P. Quaglio,P. Effect of Eucalyptus essential oil on respiratory bacteria and viruses. Current Microbiology. 2008;56(1),89-92.

17. Boukhatem MN, Amine FM, Kameli A, Saidi F, Walid KS, Bouziane M. Quality assessment of the essential oil from Eucalyptus globulus Labill of Blida (Algeria) origin. Int Let Chem Phys Astro. 2014;17:303-15.

18. Batish DR, Singh HP, KohliRK, Kaur S. Eucalyptus essential oil as a natural pesticide. Forest Ecol. Manag. 2008;256:2166-74.

19. Goldbeck J, do Nascimento JE, Jacob RG, Fiorentinia ÂM, da Silva WP. Bioactivity of essential oils from Eucalyptus globulus and Eucalyptus urograndis against planktonic cells and biofilms of Streptococcus mutans. Ind Crops Prod. 2014;60:304-9. 
20. Ramos AS, Ribeiro JB, Teixeira BG, Ferreira JLP, Silva JRA, Ferreira AA et al. Hydroxylation of 1,8-cineole by Mucorra mannianus and Aspergillus niger. Braz. J. Microbiol. 2015;46(1):261-64.

21. Rossi YE, Palacios SM. Insecticidal toxicity of Eucalyptus cinerea essential oil and 1,8-cineole against Musca domestica and possible uses according to the metabolic response of flies. Ind Crops Prod. 2015;63,133-37.

22. Mac Laughlin JL, Rogers LL. Drug Information Journal. 1998:513.

23. Harkat-Madouri L, Boudria A, Khodir M, Bey-Ould Z, Si Saida $\mathrm{K}$, Rigouc PD, et al. Chemical composition, antibacterial and antioxidant activities of essential oil of Eucalyptus globulus from Algeria. Ind Crops and Prod.2015;78:148-53.

24. Olayinka AJ, Olawumi OO, Olalekan AM, Abimbola AS, Idiat ID, Theophillus OA. Chemical composition, antioxidant and cytotoxic effects of Eucalyptus globulus grown in north -central Nigeria. J Nat Prod Plant Resour. 2012;2(1):1-8.

25. Russo S, Cabrera N, Chludil H, Yaber-Grass M, Leicach S. Insecticidal activity of young and mature leaves essential oil from Eucalyptus globulus Labill.againstTribolium confusum Jacquelin du Val (Coleoptera: Tenebrionidae). Chi J Agric Res. 2015;75:375-79.

26. Derwich E, Benziane Z, Boukir A. GC/MS analysis of volatile constituents and antibacterial activity of the essential oil of the leaves of Eucalyptus globulus in Atlas Median from Morocco. Adv Nat Appl Sci. 2009;3:305-13.

27. Mossi AJ, Astolfi V, Kubiak G, Lerin L, Zanella C, Toniazzo $\mathrm{G}$ et al.Insecticidal and repellency activity of essential oil of Eucalyptus sp. against Sitophilus zeamais Motschulsky (Coleoptera, Curculionidae). J Sci Food Agr. 2011;91:273-77.
28. Bruneton J. Pharmacognosie - Phytochimie, Plantes Médicinales, 2ème éd., Tec et Doc. Editions Médicales Internationales, Paris; 2008:1188.

29. Barbosa LCA, Filomeno CA, Teixeira RR. Chemical Variability and Biological Activities of Eucalyptus spp. Essential Oils. Molecules. 2016;21(12):1671.

30. Chagas ACS, Passos WM, Prates HT, Leitem RC, Furlong J, Fortes ICP. Acaricide effect of Eucalyptus spp. EOs and concentrated emulsion on Boophilus microplus. Braz J Vet Res Ann. Sci. 2002;39:247-53.

31. Yang Y, Choi H, Choi W, Clark JM, Ahn Y. Ovicidal and adulticidal activity of Eucalyptus globulus leaf oil terpenoids against Pediculus humanuscapitis (Anoplura: Pediculidae). J Agric Food Chem. 2004;52:2507-11.

32. Lucia A, Licastro S, Zerba E, MasuhH. Yield, chemical composition, and bioactivity of EOs from 12 species of Eucalyptus on Aedesaegypti larvae. Entomol Exp Appl. 2008;129:107-14.

33. Karemu, C.K., Ndung'u, M.W., Githua, M. Repellent effects of EOs from selected Eucalyptus species and their major constituents against Sitophilus zeamais (Coleoptera: Curculionidae). Int. J. Trop. Insect Sci. 2013;33:188-94.

34. Taleb-Toudert K. Extraction et caractérisation des huiles essentielles de dix plantes aromatiques provenant de la région de Kabylie (Nord Algérien). Evaluation de leurs effets sur la bruche de niébé Callosobruchus maculatus (Coleoptear: Bruchidae). Thèse de Doctorat. Université Mouloud Mameri, Tizi Ouzou, Algeria; 2015.

35. Gende L, Maggi M, van Baren C, di Leo A, Bandoni A, Fritz R et al. Antimicrobial andmiticide activities of Eucalyptus globulus essential oils obtained from different Argentine regions. Spa J of Apicul Res. 2010;8(3). 